\title{
Pakistani Youth in Relation to CPEC and Their Future as Entrepreneurs
}

\section{La juventud pakistaní en relación con CPEC y su futuro como emprendedores}

Received: September 14, 2020

\begin{abstract}
The objective of the study is to reveal whether the Pakistani youth accepts CPEC as their future and have shown positivity to become an entrepreneur. Our study reveals that; the youth in Pakistan feels that it is a need of time for their country and to take this opportunity as positive indicator towards their country prosperity and economic revival in no times. The research is focused on the samples based upon the youth of Lahore specifically the university students who directly have impact over being the entrepreneurs of Pakistan We use frequency analysis for our resultants, that helps us to interpret the data at a glance initially for the subject problem identified. It also helps us to evaluate and highlight the factors involved with the composition of its involvement as variable.
\end{abstract}

Abstract

Keywords: CPEC, Youth, Entrepreneurship, Government Initiative \& Prosper Country.

\section{Introduction}

CPEC is the most imperative step in the historical backdrop of Pakistan-China participation by which the destiny of Pakistan will change and help in huge capacity individuals in respective areas, " China's rapid progress was made possible when it opened its doors to the world and created special economic zones to attract foreign direct investment" (Abdul, 2016). "Pakistan CPEC is the most grounded mainstay of monetary, business and social network among Pakistan and China and its local effect will be exceptionally positive. The system of streets, railroads and modern parks will proclaim another period of
Accepted: November 10, 2020

Written by:

Imran Yousuf Muhammad ${ }^{11}$ https://orcid.org/0000-0001-6652-178X Ali Raza Qureshi ${ }^{12}$

\section{Resumen}

El objetivo del estudio es revelar si los jóvenes paquistaníes aceptan CPEC como su futuro y han mostrado positividad para convertirse en emprendedores. Nuestro estudio revela que los jóvenes de Pakistán sienten que es una necesidad de tiempo para su país y aprovechar esta oportunidad como indicador positivo hacia la prosperidad y la reactivación económica de su país en muy poco tiempo. La investigación se centra en las muestras basadas en la juventud de Lahore específicamente en los estudiantes universitarios que tienen un impacto directo sobre ser los empresarios de Pakistán Usamos análisis de frecuencia para nuestros resultados, que nos ayudan a interpretar los datos de un vistazo inicialmente para el problema de la asignatura. identificado. También nos ayuda a evaluar y destacar los factores que intervienen en la composición de su implicación como variable.

Palabras Clave: CPEC, Juventud, Emprendimiento, Iniciativa Gubernamental y País Prosper.

advancement and thriving to profit three billion individuals" (China South Asia Business Forum, 2016). The ties between China and Pakistan is becoming more strengthen with the passage of time with a distinct advantage of being sincere to each other, in regards to this both the nations have marked new standards in the monetary aspect which increases significantly in recent past. Pakistan being one of the most prominent countries in the globe providing security to all stake holders with a financials of \$46-billion venture.

\footnotetext{
${ }^{11}$ Dr. by Profession, Entrepreneur, \& Lead Trainer at Transformation International, Preston University, Karachi Pakistan

${ }^{12}$ Educationist, Trainer and Quality Expert, Preston University.
} 
A significant achievement in South Asian territorial mix was China's plan to construct two calculated supply routes in this area. During the visit to Pakistan in May 2013, Prime Minister of China Li Keqiang recommended a financial hallway between China and Pakistan to connect Chinese Kashgar Pakistan as the principal nation of South Asia which considers as marking such a super venture arrangement in 2014. Pakistan is by all accounts the second-biggest exchange accomplice of China and China is the greatest speculator in various fields as media communications, energy areas, Ports, framework two-sided training, and individual's contacts. The ongoing CPEC activities among Pakistan and China make Pakistan the most punctual travel pointhub for the second biggest economy of the world among the nations of South Asia the southwestern Gwadar port of Pakistan (Memoona et al, 2014).

"The absence of political amicability would be the major challenge towards the usage of the China Pakistan Monetary Corridor (CPEC) venture in Pakistan" (Falak, 2014). "Pakistan and China have power over many lands connections that give admittance to the asset-rich area" (Bhutta, 2015). "CPEC is the ideal undertaking which will help the freed the nation of the energy emergencies. Energy accessibility in the nation will resuscitate existing enterprises, for example, material to full creation and add an expected 2 percent to Pakistan's GDP development" (Akram, 2015). "It is imperative to plan and execute the undertakings productively. The CPEC ought not to turn into a casualty to political infighting and regulatory torpidity. The multidimensional activity appreciates the help of the top authority in the two nations. It is trusted that it would help understand the destinations of financial improvement of the two nations" (Jaspal, 2016). "For Pakistan the ideal financial targets of CPEC incorporate a plainly spread out arrangement for its execution including job tasks, expected commitment and undisputed compensations for all partners included. The infrastructural advancement under CPEC should zero in on towns, little urban communities, and provincial zones. The indigenous items like agribusiness ought to be advanced through the transportation hall. The administration should reserve explicit Chinese business sectors for Pakistani items, and arrange tax rates with the Chinese government" (Daily Dawn, 2017). "A significant achievement in South Asian territorial combination was China's plan to fabricate two calculated supply routes in this locale. During the visit to Pakistan in May 2013, Prime Minister of China recommended a financial hall among
China and Pakistan to connect Chinese Kashgar with the southwestern Gwadar port of Pakistan" (Keqiang, 2013).

Dr. Ishrat Hussain in his review analysis stated, that; "It will be the imaginable result of CPEC especially relies on our aggregate reaction limit for example of the Federal, commonplace and neighborhood governments, the private area, the media, and the common society all cooperating as one and cooperatively. In the event that that occurs, the advantages to the Pakistani economy and society especially Baluchistan and Southern $\mathrm{KP}$ are probably going to surpass the expenses. However, in the event that we proceed with the Business as a typical mode where quarreling, habitual pettiness, point scoring, restricted parochial and individual contemplations, formality, faltering and deferrals in taking care of issues and eliminating bottlenecks persevere then we would absolutely end up entangled in substantial budgetary weight. The decision is totally our own and not that of our Chinese accomplices" (Hussain, 2017).

China Mesmerizing Economic Pathway to Success (OBOR): OBOR initiative been taken by the Chinese, they have taken stance to have such ventures with others too. The economic ties and economic war declaration is a step to take the world as their business hub. The venture of OBOR SIX is now on the high rise and the ties with all the natives are now getting energized by pouring \$4-8 Trillion in the market. The OBOR SIX has changed the dimensions and strategic power game from America to China. It contains following multiple corridors in the regions of Asia, Europe, and Eastern parts of the world.

Dr. Ishrat Hussain in his book CPEC and Pakistani Economy: an Appraisal, stated that; "Taking everything into account, upwards of sixty nations would get associated with China through an organization of streets, parkways, railroads, pipelines, matrices, and fiber optics. This availability at its pinnacle would additionally improve the intensity of Chinese products and enterprises by decreasing the exchange costs and facilitating conveyance time. China is now flooding the worldwide business sectors with its moderately modest merchandise and has become the top sending out country of the world. Its relative bit of leeway would consequently be continued over the long haul. Its situation as a magnet for the worldwide gracefully chain would be additionally fortified" (Hussain, 2017). 


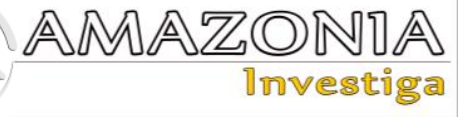

\section{Literature Review}

Focal neighborhood relations are a center yet risky issue in China's change cycle. The customary way of thinking is that the financial changes have extensively debilitated control by the focal government over monetary exercises in the territories. Political ramifications are gotten straightforwardly from these financial perceptions. The common view is that the monetary changes have diminished the political control of the middle and for sure have raised doubt about the feasibility of China as a solitary political element. It shows that monetary decentralization has been joined by a fortifying of China's unitary political framework. This has direct course on nearby financial lead. Due to the political and institutional imperatives, nearby authorities give up charge incomes to the focal government and check their inflationary speculation interest (Yasheng, 1996). Despite all issues the huge investment in the form of funds with $\$ 40$ Billion has been set up to regulate the CPEC Initiative. The co related efforts in the area of asset and financial management was incorporated in the framework. The investment funds are welcomed by the support from residential and abroad financial specialists. "The main capital establishment of the Fund adds up to US\$10 billion.

The President of China addresses at the Belt and Road Forum, announced that the government will invest in to develop the best of the infrastructure and would pour in extra Billions of Yuan to facilitate the Silk Road Fund (Xi, May 2017).

Cooperation Areas: Five noteworthy objectives of the OBOR: approach to co-operational management system and their implications over the execution of project. With respect to points of interest, game plan with co-arrangement suggests that countries along with the belt and road will be on a proportionate equalization. Improvement structures and measures for pushing crossnational co-movement resolve issues rising up out of co-task through gathering and commonly give methodology backing to practical co-errand and broad scale adventure execution. With the ultimate objective to support unhindered trade, steps will be taken to decide adventure and trade help issues, decrease hypothesis and trade limits, cut down trade and theory expenses, and furthermore to propel regional money related compromise. Tries will in like manner be made to broaden the degree of trade, move trade headway through theory, and strengthen co- action in the business chain with each and every related country.

Major considerations of Cooperation: CPEC, Belt and Road Initiative have major five areas of concerns (HKTDC, 2018);

\section{Coordinated policy efforts}

Nations along the belt and street will, by means of the interview on an equivalent balance, together define improvement plans and measures for propelling cross-public or local collaboration and settling issues emerging from participation through conference (HKTDC, 2018).

\section{Infrastructural facilities}

Endeavors will be made to propel the development of port foundation offices and clearing land-water multi-purpose transport sections, meaning to set up a framework network associating different Asian sub-locales with different pieces of Asia, Europe, and Africa (HKTDC, 2018).

\section{Trade as a benefit}

Steps will be taken to determine speculation and exchange help issues decrease venture and exchange obstructions and advance local monetary coordination (HKTDC, 2018).

\section{Integrated financial regulations}

Moves will be made to extend the extent of nearby money repayment and cash trade in exchange and venture between nations along the course, develop multilateral and reciprocal budgetary participation and improve the capacity to oversee monetary dangers through local game plans (HKTDC, 2018).

\section{Interconnectivity as opportunity}

Endeavors will be made to advance trades and discoursed between various societies to frame the reason for the progression of local collaboration.

\section{CPEC as entrepreneurship excellence}

Hamza Orakzai in his speech explains, "The One Belt, One Road Initiative, the mother task of CPEC is set to change the financial and political elements in our district, yet over the globe and open door for everybody" (Orakzai, 2020).

Opening of borders to decentralization: China's provincial modern area has been the motor driving a significant part of the Chinese economy's dynamism during the change time frame. The nature and improvement of this area additionally alluded to as municipality and town undertakings (TVEs) challenge simple clarification. Across areas, there is sensational 
variety in property rights among TVEs, going from neighborhood government possession to through and through private proprietorship (Whiting, 2001). China's change period concurred with another phase of globalization controlled by quick decreases in the expense of transport, correspondence, and data administration. Subsequently, global markets have given China openings paves an enormous path way of the success in the far eastern region with excisable and developmental structure. The motive is to create a balance of economic power in the world and to curtail the trade deficit by in large. This furthermore; supports the underdeveloped country's man power wage rates. The spin of the development wheel has created a stance of improvement and a wave of tremendous change in making economy strong along with the partners associated.

The ongoing century highlights the presence of China as the steering wheel of financial growth. The experimentation of this initiative has sketched the revival 360 . We see the national government leading preliminaries of novel establishments, for instance, "unique monetary zones," while territories and areas build up their own varieties of the family unit obligation framework, township and town enterprises, the Xiagang arrangement of expelling excess specialists from the state undertaking payrolls, et cetera. The decentralization of industry is with the governmental level at the mid-tier and dependent upon the framework. The 1994 financial changes, allocated real income streams to commonplace and nearby organizations in the two urban communities and the wide open, furnished local and neighborhood governments with plentiful assets with which to seek after such experimentation.

Power and Regime (Super Power): The era of change was in between late 70's to mid-90 because of the divided power/autonomy of China as regime. The writing on veto players focuses on being formalized in structure, and formally China has veto power. What's more, balances - just the feeble "complementary responsibility" portrayed prior - and no one has the specialist to veto a Politburo choice. Be that as it may, under a framework of dictator rule, control is frequently customized and practiced casually. This was especially valid in China, and it is fundamental to look at the casual, and also the formal, dissemination of intensity at the highest point of the chain of command. No unmistakable hypothesis or wording exists to portray the circulation of control in tyrant frame works, however in China during the 1980s it is generally simple to distinguish twelve or so pioneers who had viable veto control over some part of monetary strategy. Additionally, a large portion of the essential veto players at the best had broad support systems reaching out down through the progressive framework, additionally confusing arrangement execution.

Pakistan as an Opportunity: Pakistan isn't just a single of the most youthful nations in its district, yet in addition on the planet. Sixty four percent of the nation's populace is younger than 29 , with somewhere in the range of 30 percent between the ages of 15 and 29. For in any event the following three decades, Pakistan will keep on being a more youthful nation. Never have the open doors for social, financial and political advancement been so incredible. Nor have the difficulties confronting us at any point been all the more squeezing. As in numerous nations, however more than in most, Pakistan faces an imperative chance - to be sure, an obligation - to put its young at the plain focus of its improvement needs. On the off chance that there is one most imperative exercise of this Report, it is the need to put resources into Pakistan's childhood today, to guarantee a superior future tomorrow.

Pakistan can take profits by the China-Pakistan Economic Corridor (CPEC, 2017) by getting sorted out preparing and helping youth in upgrading their business thoughts on monetary administration, development systems, advertising and key organizations (Orakzai, 2020).

Pakistan as of now has the biggest age of youngsters ever in its history, with around $66 \%$ of the aggregate populace under 30 years old. This incorporates kids under 15 will's identity tomorrow's childhood. The adolescent companion characterized as those between 15-29 years old, at present structures about $33 \%$ of the nation's aggregate populace. As a segment of the people that is traveling to adulthood, this 'adolescent lump' will end up being either a profit or a fiasco for the nation, contingent upon how Pakistan puts resources into its advancement. The Pakistan National Human Development Report 2017 in this way centers on the young as a basic power for forming human advancement.

CPEC and Achievements: CPEC will overwhelmingly settle upon its ability to give occupations and redesign financial freedom to the stakeholders. At present, joblessness and poor money related prospects for the young age speak to a real peril to the zone's progression. 


\section{AMAZZOND用}

More unfortunate access to the quality preparing and hindered work open entryways for the youthful of Baluchistan bothers their predicament. It is incredibly inconvenient for them to improve universities and find proper work in various pieces of the country. In addition, the organization has usually been the focal director in the area anyway late methodologies has directed creation of occupations as a rule society fragment. With the ultimate objective to oblige adjacent laborers in the CPEC related endeavors, it is basic that the organization arranges thought towards structure up their aptitudes. If adequate undertakings are not made in human resource progression, by then, only a little measure of adjacent work power will benefit by the CPEC. In this way, there won't be any significant progression in keeping an eye on the threats in the zone.

The structure for Pakistan's money related improvement, orchestrated by the legislative specialists of Pakistan, features that the human insufficiency is an experiment to Pakistan's economy in connection to the availability of system. It is ordinary that the CPEC will make work for the adjacent masses in the fundamental stage anyway measures must be taken with the ultimate objective to consolidate the increments. The Deputy Chairman of Planning Commission of Pakistan, Dr. Nadeem-ul-Haque, pointed out that progression stretches out in Pakistan require the key course to pass on monetary advantages. In this manner, to develop work openings, the measure of endeavor must be enhanced by appropriate organizing and human improvement exercises.

\section{Benefits}

As a feature of framework ventures worth around $\$ 11$ billion, and 1,100-kilometer-long motorway will be developed between the urban areas of Karachi and Lahore (Dawn, 2014), while the Karakoram Highway among Rawalpindi and the Chinese outskirt will be totally reproduced and updated. The Karachi-Peshawar fundamental railroad line will likewise be moved up to consider trains go at as much as 160 kilometers for each hour by December 2019 (The Asia Dialogue, 2017).

Pakistan's railroad organization will likewise be stretched out to inevitably associate with China's Southern Xinjiang Railway in Kashgar (Zhen,
2015). An organization of pipelines to ship condensed petroleum gas and oil will likewise be laid as a feature of the task, including a \$2.5 billion pipeline among Gwadar and Nawabshah to move gas from Iran (Shah, 2015).

Oil from the Middle East could be offloaded at Gwadar and moved to China through the hall, cutting the current $12,000 \mathrm{~km}$ excursion to 2,395 $\mathrm{km}$. It will go about as a scaffold for the new Maritime Silk Route that conceives connecting 3 billion individuals in Asia, Africa, and Europe, part of a trans-Eurasian venture. When completely operational, Gwadar will advance the financial improvement of Pakistan and become an entryway for Central Asian nations, including Afghanistan, Uzbekistan, connecting Sri Lanka, Iran, and Xinjiang to embrace marine vehicle (Ting. 2015).

\section{Research Methodology}

As our research is subject to gets the information about youth as being entrepreneur is a success under the national project named CPEC is presumed, for which at this initial stage the frequency analysis helps in identifying the factor highlighted. Through frequency analysis the glance of the data helps identifying the exact fields of interest. This comprises college students $\mathrm{M} / \mathrm{F}$ both in the city of Lahore with the close ended questionnaire for accuracy of results. The sample of 455 students was collected and tabulated in the form of pie chart for clear understandings.

\section{Sampling Model}

Sample Population: This investigation is completely founded on choice of respondents as possible partners in the locale of Lahore, It is thought to be more than .1 million assessed, with no layers or gatherings in them, as in our city lion's share of the young is looking forward and sought after their profession after their fulfillment of Higher Education.

Sampling Methodology: The Population chose in the Lahore zone moreover sorts with comfort of approach in choosing four colleges Public and Private both with an example size of $600+$ understudies.

Sample Size: Qualtrics.com is the main source in the calculations. 
Confldence Level:

$95 \%$ v

Populatlon SIze:

100000

Margln of Error:

$5 \% \quad$

\section{Ideal Sample SIze:}

383

Figure No. 1. Sampling Calculation.

However as the study is time bound the time frame is distributed into deliverables which becomes due for submission at regular intervals from all the four selected universities Lahore.

\section{Results}

The results validate the arguments through a detail set of questionnaire and get supported to identify the factors involved by drawing a clear percentage corresponding to the questions raised to qualify the objective of the study. Hence through rigorous examination following results achieved for the betterment of the study which helps the community to develop their stance and understanding for the subject acceptance.
A narrative was built considering general concerns about CPEC awareness amongst Pakistani youth and the opportunities they are expecting from it. Based on that an online questionnaire was prepared related to CHINAPAKISTAN ECONOMIC CORRIDOR (CPEC) and shared with four Public / Private Universities. The questionnaire along with responses (455) in the form of pie or circle chart is as follows:

Q1. Do you think China-Pakistan Economic Corridor will bring peace and prosperity in South Asia?

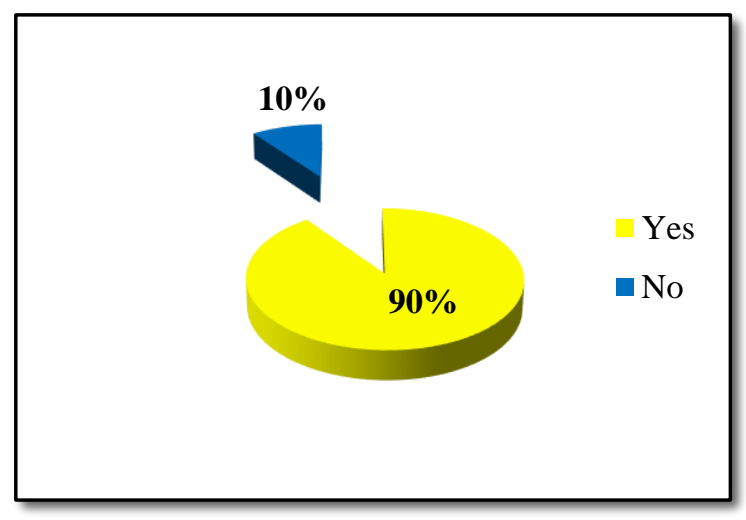

Figure No. 2.

Q2. Do you feel CPEC will provide best opportunities for the Pakistani youth to contribute in following areas? a. Strengthening Economy

b. Developing Infrastructure

c. Building Bilateral Relationship 


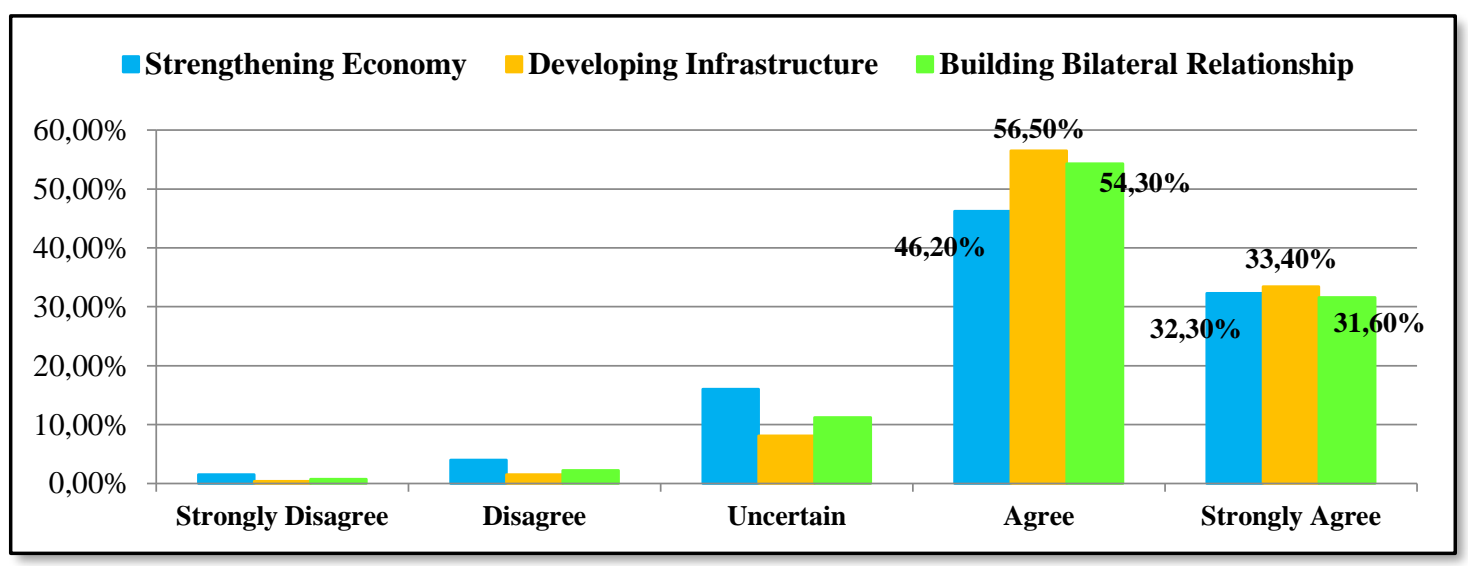

Figure No. 3.

Table No. 1

\begin{tabular}{lllllll}
\hline & $\begin{array}{l}\text { Strongly } \\
\text { Disagree }\end{array}$ & Disagree & Uncertain & Agree & $\begin{array}{l}\text { Strongly } \\
\text { Agree }\end{array}$ & $\begin{array}{l}\text { Total } \\
(\mathrm{SA}+ \\
\mathrm{A})\end{array}$ \\
\hline Strengthening Economy & $1.50 \%$ & $4.00 \%$ & $16.00 \%$ & $\mathbf{4 6 . 2 0 \%}$ & $\mathbf{3 2 . 3 0 \%}$ & $\mathbf{7 8 . 5 \%}$ \\
Developing Infrastructure & $0.40 \%$ & $1.50 \%$ & $8.10 \%$ & $\mathbf{5 6 . 5 0 \%}$ & $\mathbf{3 3 . 4 0 \%}$ & $\mathbf{8 9 . 9 \%}$ \\
Building Bilateral Relationship & $0.70 \%$ & $2.20 \%$ & $11.20 \%$ & $\mathbf{5 4 . 3 0 \%}$ & $\mathbf{3 1 . 6 0 \%}$ & $\mathbf{8 5 . 9 \%}$ \\
\hline
\end{tabular}

Q3. Do you feel CPEC Pakistani youth be benefitted from CPEC in following sectors?
a. Engineering
b. IT
c. Renewable Energy
d. Basic Sciences

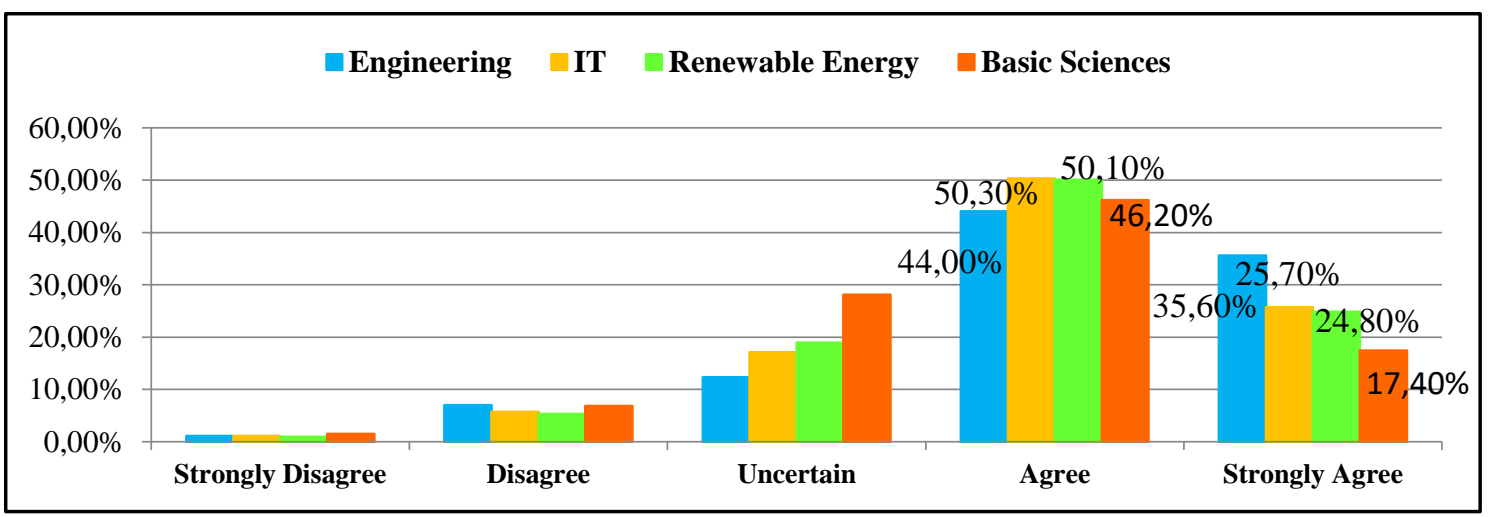

Figure No. 4.

Table No. 2

\begin{tabular}{lllllll}
\hline & $\begin{array}{l}\text { Strongly } \\
\text { Disagree }\end{array}$ & Disagree & Uncertain & Agree & $\begin{array}{l}\text { Strongly } \\
\text { Agree }\end{array}$ & $\begin{array}{l}\text { Total } \\
(\mathrm{SA}+ \\
\mathrm{A})\end{array}$ \\
\hline Engineering & $1.10 \%$ & $7.00 \%$ & $12.30 \%$ & $\mathbf{4 4 . 0 0 \%}$ & $\mathbf{3 5 . 6 0 \%}$ & $\mathbf{7 9 . 6 \%}$ \\
IT & $1.10 \%$ & $5.70 \%$ & $17.10 \%$ & $\mathbf{5 0 . 3 0 \%}$ & $\mathbf{2 5 . 7 0 \%}$ & $\mathbf{7 6 \%}$ \\
Renewable Energy & $0.90 \%$ & $5.30 \%$ & $18.90 \%$ & $\mathbf{5 0 . 1 0 \%}$ & $\mathbf{2 4 . 8 0 \%}$ & $\mathbf{7 4 . 9 \%}$ \\
Basic Sciences & $1.50 \%$ & $6.80 \%$ & $28.10 \%$ & $\mathbf{4 6 . 2 0 \%}$ & $\mathbf{1 7 . 4 0 \%}$ & $\mathbf{6 3 . 6 \%}$ \\
\hline
\end{tabular}


Q4. Reaping full potential of CPEC in benefits, Pakistan needs to improve the following three prerequisites;

a. Investment in developing institutions, by restructuring to improve legal frameworks, to implement rule by political stability.

b. Infrastructural Development of commute systems

c. Development by technical and formal education

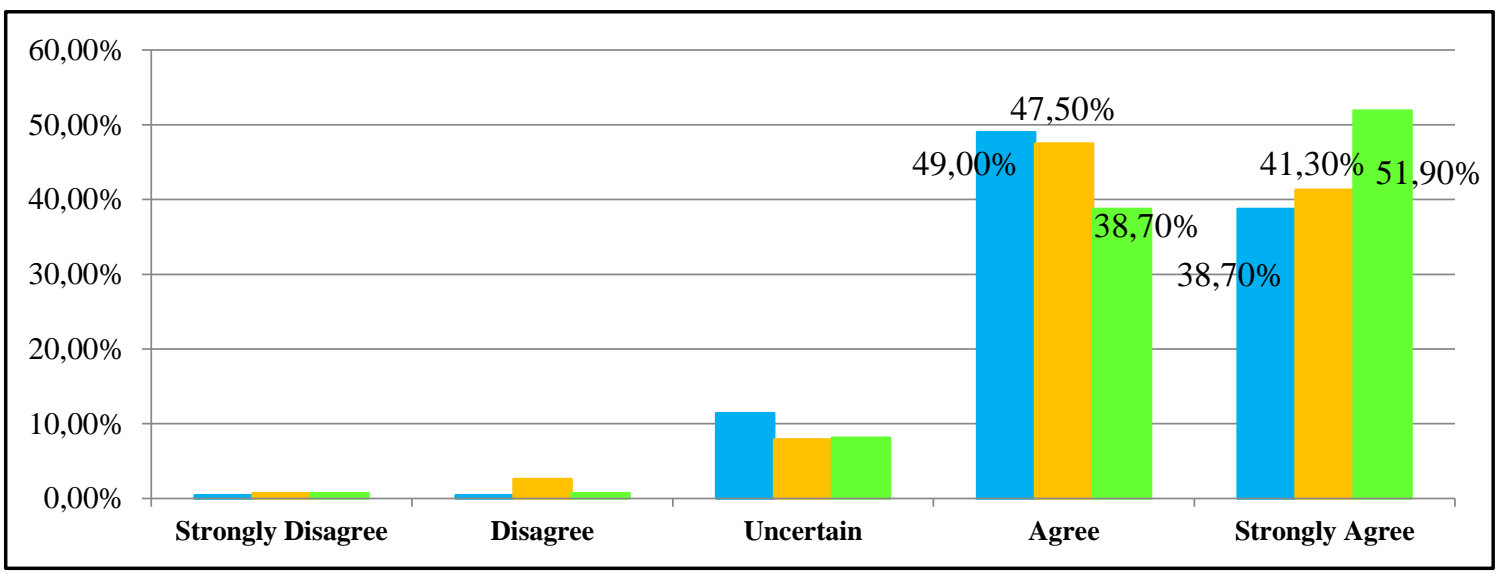

Figure No. 5

Table No. 3

\begin{tabular}{|c|c|c|c|c|c|c|}
\hline & $\begin{array}{l}\text { Strongly } \\
\text { Disagree }\end{array}$ & Disagree & Uncertain & Agree & $\begin{array}{l}\text { Strongly } \\
\text { Agree }\end{array}$ & $\begin{array}{l}\text { Total } \\
(\mathrm{SA}+ \\
\mathrm{A})\end{array}$ \\
\hline $\begin{array}{l}\text { Investment in developing } \\
\text { institutions, by restructuring to } \\
\text { improve legal frameworks, to } \\
\text { implement rule by political } \\
\text { stability. }\end{array}$ & $0.40 \%$ & $0.40 \%$ & $11.40 \%$ & $49.00 \%$ & $38.70 \%$ & $87.7 \%$ \\
\hline $\begin{array}{l}\text { Infrastructural Development of } \\
\text { commute systems }\end{array}$ & $0.70 \%$ & $2.60 \%$ & $7.90 \%$ & $\mathbf{4 7 . 5 0 \%}$ & $41.30 \%$ & $88.8 \%$ \\
\hline $\begin{array}{l}\text { Development by technical and } \\
\text { formal education }\end{array}$ & $0.70 \%$ & $0.70 \%$ & $8.10 \%$ & $38.70 \%$ & $51.90 \%$ & $90.6 \%$ \\
\hline
\end{tabular}

Q5. How well Pakistani youth is prepared to reap the benefits of CPEC?

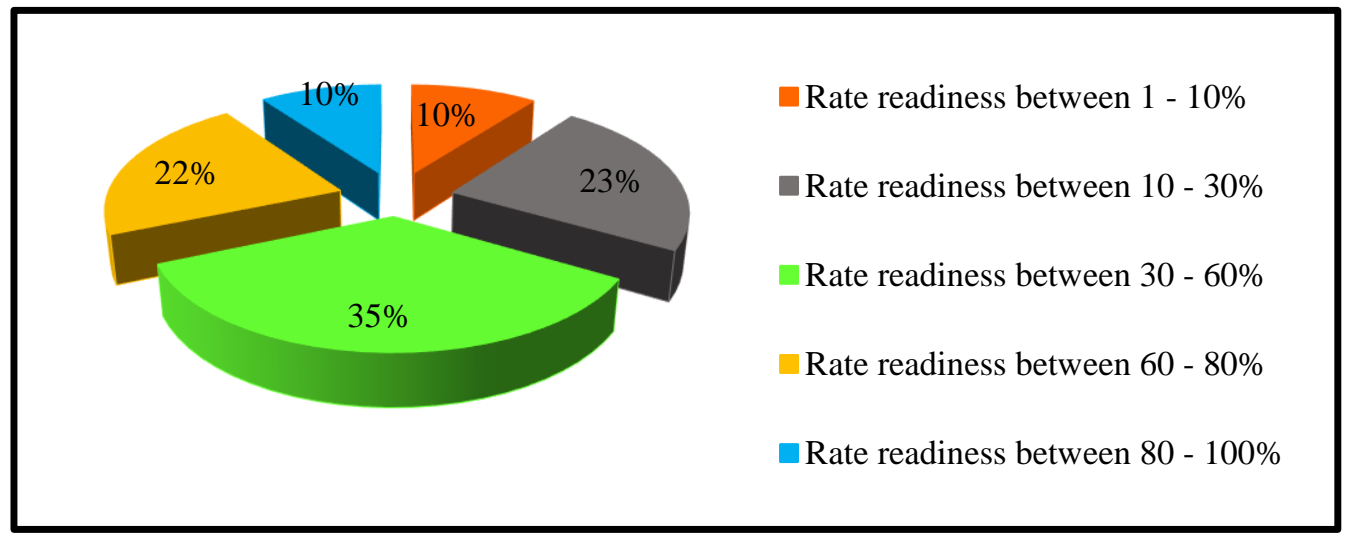

Figure No. 6 
Table No. 4

\begin{tabular}{ll}
\hline Rate readiness between $1-10 \%$ & $\mathbf{1 0 . 3 0 \%}$ \\
\hline Rate readiness between $10-30 \%$ & $\mathbf{2 3 . 1 0 \%}$ \\
Rate readiness between $30-60 \%$ & $\mathbf{3 5 . 2 0 \%}$ \\
Rate readiness between $60-80 \%$ & $\mathbf{2 1 . 5 0 \%}$ \\
Rate readiness between $80-100 \%$ & $\mathbf{9 . 9 0 \%}$ \\
\hline
\end{tabular}

\section{Results/Findings}

Interestingly $90 \%$ of respondents believe ChinaPakistan Economic Corridor will bring peace and prosperity in South Asia but only $10 \%$ believe Pakistan is fully ready to reap the benefits of CPEC.

$22 \%$ respondents think we are partially ready. It shows the enlightenment of the people about the benefits of CPEC but also depicts the concern that we are not ready of as per $70 \%$ of the responses.

When asked in second question about the opportunities for contribution by youth in the areas of Strengthening Economy, Developing Infrastructure \& Building Bilateral Relationship we see similar patterns in all three fields as overwhelmingly more than $80 \%$ have shown positive response. If we look a little deeper on average it shows $30 \%$ strongly agree and 50\% agree about opportunities available for youth to contribute in the said areas. Uncertainty and disagreement level also remains which are almost negligible.

In reference to question three, responses are also overwhelming as on average more than $75 \%$ respondents are positive when asked about the benefits of the youth in the fields of Engineering, IT and Renewable Energy. The percentage of positive response declines to $64 \%$ for the field of Basic Science may be students are inclined more towards "Engineering" and "IT". Disagreement level around 6\% remains same for all mentioned fields.

$90 \%$ of agreement level in responses against question four clearly depict the awareness level that as a country we need to fulfil following prerequisites to reap the full potential of the CPEC.

$39 \%$ strongly agree and $49 \%$ agree on needs to invest in institutions with restructuring in legal frameworks.
$41 \%$ strongly agree and $48 \%$ agree with the requirement of development of local road and transport systems.

$52 \%$ strongly agree and $39 \%$ agree development of human capital through extensive trainings.

\section{Developmental conclusion of the study}

Under the factor of peace and prosperity results, the decision makers should create more favorable condition for the youth to take part in all such activities that promotes the CPEC in general as well as in specific. This factor serve as an umbrella achievement to the youth that the confidence lies within, thus their involvement in such projects or such projects creates avenues for their future is evident. The study results revealed the better prospects for the youth as capacity building and future entrepreneurial excellence. China Pakistan Economic Corridor (CPEC) is a collection of infrastructure development, power generation and Research \& Development project valued $\$ 46$ - $\$ 62$ billion as of 2017. It is evident through the data that the Youth in Pakistan is in will to accept a change in the area of infrastructural development vis-à-vis' improvement in their living standards. The acceptance in overall challenges the Government to put their best efforts to reap the benefits for the youth, which is only possible once you know your value and readiness. There is a need to carry out further study on Gap analysis, In accordance with number of questions aroused to further highlight the position and stake of the youth in such developmental heavy budgeted projects. The project stake holders' confidence is to be measured in terms of their presence and confirmation of the completion of project in due time and budget.

\section{Bibliographic References}

Abdul, A. R. (2016). The history of Pak-China cooperation CPEC most important project: FPCCI. Retrieved from the website: https://fp.brecorder.com/2016/06/20160615568 03/ 
Akram, M. (2015, 26 April) The cup and the lip. The Dawn. Retrieved from the website https://www.dawn.com/news/1178215

Asia Dialogue. (2017). How will CPEC boost Pakistani economy? Retrieved from the website https://theasiadialogue.com/wp-

content/uploads/2017/04/pak-china-eco-

corridor-deloittepk-noexp.pdf

Bhutta, Z. (2015, October 5) Ties with Central

Asia: Poised to gain wider influence. The

Express Tribune. Retrieved from the website https://tribune.com.pk/story/967191/ties-withcentral-asia-poised-to-gain-wider-influence Business Recorder. (07 Sep. 2016). CPECformidable challenge, (2016). Retrieved from https://www.brecorder.com/news/4433678.

China South Asia Business Forum (2016). The $11^{\text {th }}$ China-South Asia Business Forum. Retrieved from http://en.csabf.com/?p=24

Daily Dawn. (Sept 18, 2017). News Report, "Breakthrough in Sino-Pak FTA talks," Retrieved from https://www.dawn.com/news/1357937/

breakthrough-in-sino-pak-fta-talks. (accessed on Sept 18, 2017)

Dawn. (2014). Karachi to Lahore Motorway Project Approved". The Dawn Media Group. $\begin{array}{lll}\text { Retrieved } 5 & 5 & \text { September } \\ \end{array}$ https://www.dawn.com/news/1116948

Falak, J. (2014). CPEC: Internal Significance and Challenges. Stratagem https://stratagem.pk/strategic-pulse/cpecinternal-signfigance-and-challenges/ HKTDC. (2018). The Belt and Road Initiative. Retrieved from website: http://china-traderesearch.hktdc.com/business-news/article/TheBelt-and-Road-Initiative/The-Belt-and-RoadInitiative/obor/en/1/1X000000/1X0A36B7.htm Hussain, I. (2017). CPES and Pakistani Economy and Appraisal. Retrieved from the website:

http://www.cpec.gov.pk/brain/public/uploads/do cuments/CPEC-and-Pakistani-Economy_AnAppraisal.pdf
Jaspal, Z. N. (2016). "CPEC: Opportunities" Pakistan Observer. October 27. 2016. http://pakobserver.net/

Keqiang, L. (2013). What is the China-Pakistan Economic Corridor? http://www.cpecinfo.com/10-questions-on-cpec (accessed on April 2, 2017)

Memoona et al. (2014). The growing economic ties between Pakistan and china and its impact on the economy of Pakistan, Impact International journal of research in humanities, arts and literature, Vol. 2, Issue 12, Page 49-54, December 2014

Orakzai, H.S (2020). Youth can benefit from the CPEC. Retrieved from the website: https://www.thenews.com.pk/print/603236youth-can-benefit-from-cpec

Shah, S. (9 April 2015). "China to Build Pipeline from Iran to Pakistan". The Wall Street Journal. Retrieved 6 December 2015

Wang, Ting. (2015). China gets 40 years rights at Pakistani ports. The Jakarta Post, Beijing. Retrieved from website: https://www.thejakartapost.com/news/2015/04/1 5/china-gets-40-year-rights-pakistani-port.html Whiting, S.H (2001). Power and Wealth in Rural China: The Political Economy of Institutional Change. Cambridge and New York: Cambridge University Press.

Xi, J. (2017). President Xi's Speech At Opening Of Belt And Road Forum, May 14, 2017. USChina Institute. Retrieved from the website: https://china.usc.edu/president-xis-speechopening-belt-and-road-forum-may-14-2017 Yasheng, H. (1996). Central-local relations in china during the reform era: The economic and institutional dimensions. World Development Vol.24, issue 4, pgs., 655-672. https://doi.org/10.1016/0305-750X(95)00160-E Zhen, S. (11 November 2015). "Chinese firm takes control of Gwadar Port free-trade zone in Pakistan". South China Morning Post. Retrieved 11 December 2015. 